\title{
Does Radiotherapy Augment Natural Killer Cell Function in Pediatric Acute Lymphoblastic Leukemia?
}

\section{Çocukluk Çăğ Akut Lenfoblastik Lösemisinde Radyoterapi Doğal Öldürü̈cü Hücre Fonksiyonların Artırır Mı?}

\section{Tuğçe Aksu Uzunhan ${ }^{1}$ (D), Zeynep Karakaş ${ }^{2}$ (D), Serap Erdem Kuruca ${ }^{3}$ (D), Muzaffer Beyza Ozansoy ${ }^{4}$ (D) Sabriye Karadenizli Taşkın ${ }^{5}$ (D), Nilgün Akdeniz ${ }^{6}$ (D), Belkıs Atasever Arslan ${ }^{7}$ (D), Günnur Deniz ${ }^{8}$ (D)}

\footnotetext{
Prof Dr Cemil Taşcioğlu City Hospital, Division of Pediatric Neurology, Istanbul, Turkey

2 Istanbul University, Istanbul Faculty of Medicine, Division of Pediatric Hematology and Oncology, Istanbul, Turkey

3 Istanbul University, Istanbul Faculty of Medicine, Department of Physiology, İstanbul, Turkey

${ }^{4}$ Istanbul Aydın University, School of Medicine, Department of Physiology, Istanbul, Turkey

${ }^{5}$ Kocaeli University, Institute of Health Sciences Department of Physiology, Kocaeli, Turkey

${ }^{6}$ Istanbul University, Aziz Sancar Institute of Experimental Medicine, Department of Immunology, Istanbul, Turkey

7 Uskudar University, Department of Molecular Biology and Genetics, Istanbul, Turkey,

University of Illinois at Chicago, College of Medicine, Department of Anatomy and Cell Biology, Chicago, CA

8 Istanbul University, Aziz Sancar Institute of Experimental Medicine, Department of Immunology, Istanbul, Turkey
}

ORCID: T.A.U. 0000-0003-0596-2690;

Z.K. 0000-0002-8835-3235;

S.E.K. 0000-0001-7878-9994;

M.B.O. 0000-0003-4228-4577;

S.K.T. 0000-0002-1402-0163;

N.A. 0000-0002-6208-3193;

B.A.A. $0000-0001-5827-8484$;

G.D. 0000-0002-0721-6213

Corresponding author/Sorumlu yazar: Tuğçe Aksu Uzunhan,

Prof Dr Cemil Taşcıoğlu City Hospital, Division of Pediatric Neurology, Istanbul, Turkey

E-mail: tugceuzunhan@yahoo.com

Submitted/Gelis tarihi: 21.12.2020

First Revision Received/İlk revizyon: 04.01.2021

Last Revision Received/Son Revizyon: 09.01.2021

Accepted/Kabul Tarihi: 20.01.2021

Citation/Atıf: Aksu Uzunhan T, Karakas Z, Erdem Kuruca S, Ozansoy MB, Karadenizli Taskin S, Akdeniz N, et al. Does radiotherapy augment natural killer cell function in pediatric acute lymphoblastic leukemia?. Sağlık Bilimlerinde İleri Araștırmalar Dergisi 2021; 4(1): 1-12. https://doi.org/10.26650/JARHS2021-842449

\begin{abstract}
Objective: The aim of this study was to investigate changes in natural killer (NK) cell proportion, NK cell activity, and cytokine levels in children with acute lymphoblastic leukemia (ALL) during and after therapy.

Materials and Methods: The study group included 33 ALL patients and the control group consisted of 11 healthy children. The ALL patients were divided into three groups, those who had completed protocol $\mathrm{M}$, receiving maintenance chemotherapy, and whose chemotherapy was discontinued. NK cell cytotoxicity was evaluated at different effector to target (E:T) cell ratios and in lytic units (LU). Expression of CD56, CD3, NKp46, CD2, CD94, NKG2D, and CD16 molecules and levels of the interferon gamma (IFN- $\gamma$ ) and interleukin-15 (IL-15) were measured. Results: NK cell activity at an E:T ratio of 1:1 was higher in patients receiving maintenance chemotherapy compared to the other groups $(p<0.05)$, but there was no difference between the groups in LU ( $>0.05)$. The ratio of CD16+CD56+ cells was smaller in the maintenance chemotherapy group compared to controls $(\mathrm{p}<0.05)$. Patients who underwent prophylactic cranial irradiation showed significantly higher NK cytotoxicity at 1:1 E:T ratio compared to those who did not $(\mathrm{p}<0.05)$. Eighty-three percent of patients in the maintenance chemotherapy group underwent prophylactic cranial irradiation. The IFN- $\gamma$ levels were significantly lower in the maintenance chemotherapy and discontinued treatment groups compared to the control group $(\mathrm{p}<0.05)$.
\end{abstract}

Conclusion: In children with ALL, chemotherapy reduces the NK cell population and IFN- $\gamma$ levels. The increase in NK cell activity in patients receiving maintenance chemotherapy may be associated with prophylactic cranial radiotherapy.

Keywords: Acute lymphoblastic leukemia, children, interferon, natural killer cells

ÖZ

Amaç: Bu çalışmanın amacı, akut lenfoblastik lösemili (ALL) çocuklarda tedavi sırasında ve sonrasında doğal öldürücü (NK) hücre oranı, NK hücre aktivitesi ve sitokin düzeylerindeki değişiklikleri araştırmaktır.

Gereç ve Yöntem: Çalışma grubu 33 ALL hastasını ve kontrol grubu 11 sağlıklı çocuktan oluştu. ALL hastaları, M protokolünü tamamlayan, idame kemoterapisi alan ve kemoterapisi kesilen olmak üzere üç gruba ayrıldı. NK hücre sitotoksisitesi, farklı efektör-hedef (E:H) hücre oranlarında ve litik birimlerde (LU) değerlendirildi. CD56, CD3, NKp46, CD2, CD94, NKG2D ve CD16 moleküllerinin ekspresyonu ve interferon gamma (IFN- $\gamma$ ) ve interlökin-15 (IL-15) seviyeleri ölçüldü.

Bulgular: 1:1 E:H oranında NK hücre aktivitesi idame kemoterapisi alan hastalarda diğer gruplara göre daha yüksek $(\mathrm{p}<0.05)$, ancak litik birimler açısından değerlendirildiğinde gruplar arasında fark saptanmadı ( $>005)$. CD16+CD56+ hücrelerin oranı, kontrollere göre idame kemoterapi grubunda daha düşük $(\mathrm{p}<0.05)$, profilaktik kraniyal radyoterapi uygulanan hastaların 1:1 E:H oranında NK sitotoksisitesi ise almayanlara göre anlamlı olarak daha yüksek saptand $1(\mathrm{p}<0.05)$. İdame kemoterapi grubundaki hastaların \%83'üne profilaktik kraniyal ışınlama uygulandı. IFN- $\gamma$ seviyeleri kontrol grubuna göre idame kemoterapi ve tedavi kesilen gruplarda anlamlı olarak daha düşük saptandı $(\mathrm{p}<0.05)$.

Sonuç: ALL'li çocuklarda kemoterapi NK hücre sayısını ve IFN- $\gamma$ düzeylerini azaltır. İdame kemoterapisi alan hastalarda NK hücre aktivitesindeki artış profilaktik kraniyal radyoterapi ile ilişkili olabilir.

Anahtar Kelimeler: Akut lenfoblastik lösemi, çocuk, interferon, doğal öldürücü hücreler 


\section{INTRODUCTION}

Natural killer (NK) cells are components of the innate immune system that do not express CD3 or T-cell receptors and are specialised in killing stressed cells (virus-infected, tumour cells) lacking MHC I antigen by secreting cytotoxins (perforins and granzymes) (1). As their importance became clearer, the functions of NK cells in various types of cancer has been evaluated both qualitatively and quantitatively (2-4). Acute lymphoblastic leukemia (ALL) is the most common type of cancer in children, accounting for $30-35 \%$ of all childhood cancers (5). In patients with ALL, the initiation of intensive combined chemotherapy causes a profound impairment of immune functions $(6,7)$. Perkins et al. evaluated immune function in 20 children with acute leukemia at the end of treatment and 6 months after treatment and observed varying degrees of immune dysfunction, including reduced or completely absent NK cell function (8). Another study showed that NK activity and IFN- $\gamma$ levels were lower compared to control subjects in 42 children with ALL during maintenance chemotherapy (9). Because NK cells play a key role in many immune events, this impact on the NK cell population may make the battle against both infection and cancer more difficult in children with ALL, whose life expectancy has increased over the past 20-30 years. Information on $\mathrm{NK}$ cell function during the various stages of treatment in children suffering from ALL may help to improve the immune function in patients under treatment or whose treatment has been discontinued, and thereby increase survival $(10,11)$. Therefore, the aim of this study was to investigate changes in NK cell numbers, NK cell activity, and cytokine levels in pediatric ALL patients during and after chemotherapy.

\section{METHODS}

\section{Subjects}

The study group included 33 ALL patients being followed in the Hematology and Oncology Unit of the Istanbul University, Istanbul Faculty of Medicine, Department of Pediatrics. The patients' sex, birth date, age, age at diagnosis, risk group, maintenance therapy initiation date, duration of maintenance chemotherapy, date of treatment cessation, treatment-free period, ALL immunophenotype, and chromosomal anomalies were recorded. The control group consisted of 11 healthy children with no medical problems. This study was approved by the Local Ethical Committee of Istanbul University, the Istanbul Faculty of Medicine, in compliance with the Helsinki declaration and written informed consents were taken from all patients subsequent to their enrolment. Part of this study has been published in Journal of Child in 2011 (12). The project has been supported by İstanbul University Scientific Research Projects (Project no T-889/02062006).

Heparinized peripheral blood samples were collected from each patient and control subjects. The ALL patients were separated into three groups, those who had completed protocol M, those who were receiving maintenance chemotherapy, and those whose chemotherapy had been discontinued. Patients in the first two groups were under treatment with the BFM TRALL 2000 protocol (13). The patients were treated with chemotherapy protocols appropriate for their risk groups. Protocol I phase 1 included prednisolone, vincristine, daunorubicin, L-asparaginase, and intrathecal (IT) methotrexate (MTX). Protocol I phase 2 included cyclophosphamide, cytosine arabinoside (ARA-C), oral 6-mercaptopurine (MP), and IT MTX. Protocol M consisted of 4 MTX infusions of $5 \mathrm{~g} / \mathrm{m}^{2}$, oral 6-MP, and IT methotrexate. High-risk (HR) patients received $6 \mathrm{HR}$ blocks. The first HR block included high-dose ARA-C, high-dose MTX, dexamethasone, cyclophosphamide, L-asparaginase, IT MTX, ARA-C, and prednisolone. Protocol II consisted of dexamethasone, vincristine, doxorubicin, L-asparaginase, cyclophosphamide, ARA-C, oral thioguanine, and IT MTX. Prophylactic cranial irradiation was performed after protocol II, immediately before maintenance chemotherapy. Oral 6-MP (50 mg/m²/ day) and oral MTX (20 mg/m²/week) were administered as maintenance therapy. The total duration of treatment in the standard-risk group was 36 months from the beginning of treatment for males and 24 months for the others. Patients whose treatment was 
discontinued had been treated with CCG-1891 (14). In this protocol, the standard-risk group was defined as a leukocyte count of $<50000 / \mathrm{mm}^{3}$ and $<10$ years of age for these patients. The high-risk group included patients with leukocyte counts $>50000 / \mathrm{mm}^{3}$ or $>10$ years of age. Criteria for the high-risk group also included the unfavourable prognostic indicators $\mathrm{t}(4 ; 11)$ and $\mathrm{t}(9 ; 22)$. Prophylactic radiotherapy was performed on all patients immediately before maintenance chemotherapy for appropriate indications and at appropriate doses (14).

\section{Cell Preparation}

Blood samples from each study subject were collected to heparin-coated blood collection tubes (BD Bioscience, San Jose, CA) and peripheral blood mononuclear cells (PBMCs) were isolated with Ficoll-Hypaque (Sigma Chem. Co., St. Louis, MO) density gradient centrifugation. The cells were washed two times with IMDM medium and prepared at a concentration of $5 \times 10^{5} \mathrm{cell} / \mathrm{s} / \mathrm{ml}$. The viability of cells was assessed using the trypan blue exclusion method (15). Medium was supplemented with 10\% heat-inactivated fetal calf serum (FCS), penicillin $(100 \mathrm{U} / \mathrm{ml})$, streptomycin $(100 \mathrm{mg} / \mathrm{ml})$ and gentamicin $(50 \mathrm{mg} / \mathrm{ml})$.

\section{Immunophenotyping}

Heparinized peripheral blood samples from all donors were processed using whole blood lysis method to measure total NK cells. PBMC cells $\left(2 \times 10^{5} \mathrm{~mL} / 1\right)$ were stained with anti-human CD56-FITC/CD16-PE, anti-human CD2-FITC, anti-human CD3-APC Cy7, anti-human CD94-PE, anti-human NKG2D-APC and anti-human-NKp46-APC and isotype controls were followed by FITC-and PE-conjugated isotype-matched mAbs (all obtained from Becton Dickinson, San Jose, USA). Following surface staining, erythrocytes were lysed with FACS Lysing Solution (BD Biosciences, San Jose, CA), cells were washed and resuspended in $2 \%$ paraformaldehyde prior to flow acquisition and analysed with BD FACSCalibur running CellQuest Software (BD Bioscience, San Jose, CA) (Figure 1).
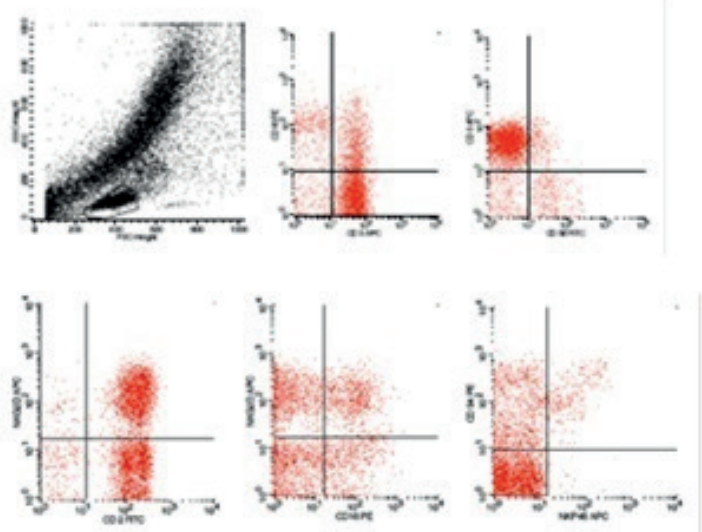

Figure 1. Flow cytometry image from a patient with acute lymphoblastic leukemia.

\section{Cytotoxicity assay}

Human erythroleukemia cells, K562, were used as target cells. PBMCs were used as the source of NK effector cells. Target cells were prepared at $5 \times 10^{5}$ cells/ $\mathrm{ml}$ and seeded indifferent ratios in 96-well U-bottom culture plates. The effector cells (E) were added to give effector/target (E/T) ratios of 1:1, 5:1, 10:1, 25:1 and 50:1. In addition, $\mathrm{E}$ and $\mathrm{T}$ cells were incubated alone in the same conditions at a final volume of 100 $\mu \mathrm{l}$ (16). Cells were incubated for $24 \mathrm{~h}$ at $37^{\circ} \mathrm{C}$ under $5 \% \mathrm{CO}_{2}$ before measuring the degree of cell killing using MTT (3-(4,5- dimethylthiazol-2yl)-2,5- diphenyl tetrazolium bromide) (Sigma, M-5655) assay (17). After incubation, the plate was loaded with $10 \mu$ of freshly prepared and filtered MTT $(5 \mathrm{mg} / \mathrm{ml}$ in PBS) and incubated for a further $3 \mathrm{~h}$. Sodium dodecyl sulfate (SDS) was added to each well in order to dissolve the formazan crystals formed by reduction of MTT by living cells. The absorbance was read at 540 nm using a microplate reader and the results were expressed as follows to yield a percentage.

$\% \mathrm{NK}$ cytotoxicity=(1-[(NK+K562avg) $-(\mathrm{NKavg})]$ /K562avg)x100

\section{Calculation of lytic units (LU)}

NK cytotoxicity results were also expressed as a single value by converting to lytic unit (LU). One LU was defined as the number of effector cells required to induce lysis in $50 \%$ of the target cells. These numbers were also divided by the $100 \%$ NK cell count $\left(10^{-5}\right)(18)$. 


\section{Cytokine Measurement}

IFN- $\gamma$ and IL- 15 concentrations were analysed in plasma samples of subjects using a commercially available (Biotek Instruments, Vermont, USA) enzyme-linked immunosorbent assay (ELISA), according to the manufacturer's manual, as previously described (19). Standards and samples were incubated with an antibody-coated 96-well micro litre plate. An enzyme-linked polyclonal antibody specific for the cytokines was then added after washing. The intensity of the colour was measured in a Biotek Instruments microplate reader at $490 \mathrm{~nm}$. Plasma collected prior to the assay was accepted as the cytokine level of unstimulated cells, while the supernatant of K562-stimulated cells at a 50:1 E:T ratio was accepted as the cytokine level after the assay.

\section{Statistical Analysis}

Statistical analyses were performed with SPSS 14.0 software (SPSS Inc., Chicago, IL, USA). One-way ANOVA was used for comparison of receptor expressions, cytokine levels and NK activity between patients and control subjects. $\mathrm{p}<0.05$ was accepted as the statistically significance level.

\section{RESULTS}

\section{Group characteristics}

Six of the patients had completed protocol M (33\% females, $66 \%$ males) and their mean age was $7.31 \pm 4.45$ years. Twelve patients ( $17 \%$ females, $83 \%$ males) with a mean age of $10.14 \pm 4.08$ years were receiving maintenance chemotherapy. There were 15 patients whose chemotherapy had been discontinued ( $40 \%$ females, $60 \%$ males; mean age $13.09 \pm 4.32$ years). Of the 11 healthy patients in the control group, 36\% were female, $64 \%$ were male, and the mean age was $8.56 \pm 3.92$ years. The mean age was significantly higher in the discontinued treatment group compared to the other groups $(\mathrm{p}<0.05)$. Age at diagnosis for the patient groups was $7.07 \pm 4.45,8.33 \pm 4.39$, and $6.56 \pm 3.92$ years, respectively. Comparisons of the patients' immunophenotypes, risk groups, chromosomal anomalies, maintenance chemotherapy durations, and treatment-free durations are shown in Table 1.

\section{Evaluation of NK activity}

NK activity was evaluated based on E:T ratios of 1:1, 10:1, 20:1, 30:1, 50:1 (Figure 2). The mean results of the NK cytotoxicity test at a ratio of $1: 1$ were $20.35 \pm 3.61 \%$ in patients who had completed protocol $\mathrm{M}, 48.22 \pm 10.78 \%$ in patients receiving maintenance chemotherapy, $24.34 \pm 16.49 \%$ in patients who finished treatment, and $20.61 \pm 10.98 \%$ in the control group. NK cytotoxicity at 1:1 E:T ratio was significantly higher in ALL patients receiving maintenance chemotherapy compared to the other groups $(\mathrm{p}<0.05)$ (Figure 2). There was no significant difference between the groups at E:T ratios of 10:1, 20:1, 30:1, or 50:1 ( $\mathrm{p}>0.05)$.

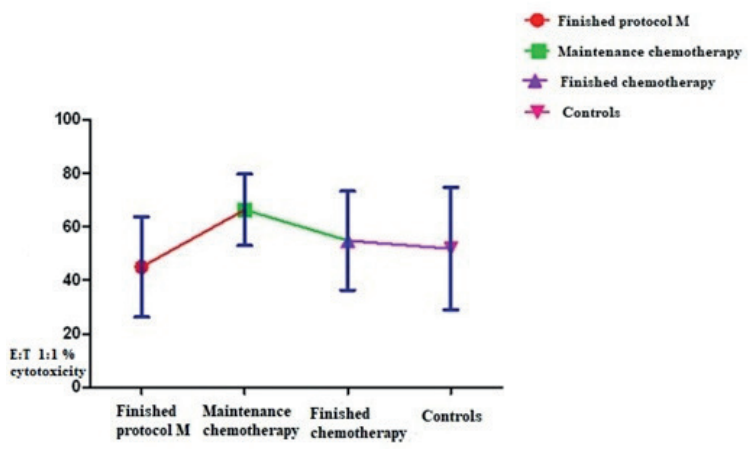

Figure 2. Natural killer cell cytotoxic activity based on groups with standard deviation values at effector to target cell (E:T) ratio of 1:1.

When NK activity was determined in lytic units (LU), mean values were $1.38 \pm 0.41 \%$ in patients who had completed protocol $\mathrm{M}, 1.77 \pm 0.64 \%$ in those receiving maintenance chemotherapy, $1.64 \pm 0.30 \%$ in those who had finished treatment, and $1.55 \pm 0.22 \%$ in the control group ( $p>0.05)$. The mean and standard deviation values from the NK cytotoxicity assay at different E:T ratios in the study groups are presented in Table 2.

\section{NK cell receptor levels}

In terms of receptor expression, the mean proportion of $\mathrm{CD} 16^{+} \mathrm{CD} 56^{+}$cells, which represents the NK cell population, was $4.04 \pm 2.64 \%$ in patients who completed protocol M, $4.00 \pm 2.04 \%$ in those receiving maintenance chemotherapy, $6.77 \pm 4.01 \%$ in patients who finished treatment, and $9.75 \pm 6.80 \%$ in controls. 
Table 1. Characteristics of the patient groups.

\begin{tabular}{|c|c|c|c|c|}
\hline & $\begin{array}{c}\text { Completed } \\
\text { protocol } M \mathrm{n}=6\end{array}$ & $\begin{array}{c}\text { Maintenance } \\
\text { chemotherapy } n=12\end{array}$ & $\begin{array}{c}\text { Treatment } \\
\text { discontinued } n=15\end{array}$ & $\begin{array}{c}\text { Control group } \\
n=11\end{array}$ \\
\hline \multicolumn{5}{|l|}{ Sex } \\
\hline Female,n (\%) & $2(33 \%)$ & $2(17 \%)$ & $6(40 \%)$ & $4(36 \%)$ \\
\hline Male, n (\%) & $4(67 \%)$ & $10(83 \%)$ & $9(60 \%)$ & $7(63.7 \%)$ \\
\hline \multicolumn{5}{|l|}{ Age (years) } \\
\hline Mean \pm SD & $7.31 \pm 4.45$ & $10.14 \pm 4.08$ & $13.09 \pm 4.32$ & $8.56 \pm 3.92$ \\
\hline Minimum & 2.67 & 2.83 & 6.42 & 2 \\
\hline Maximum & 12.25 & 16.58 & 19.17 & 13.75 \\
\hline Age at diagnosis (years) & $7.07 \pm 4.45$ & $8.33 \pm 4.39$ & $6.56 \pm 3.92$ & - \\
\hline \multicolumn{5}{|l|}{ Immunophenotype } \\
\hline B cell & $5(83 \%)$ & $5(42 \%)$ & $12(80 \%)$ & - \\
\hline T cell & $1(17 \%)$ & $7(58 \%)$ & $3(20 \%)$ & - \\
\hline \multicolumn{5}{|l|}{ Risk group } \\
\hline Standard & $3(50 \%)$ & $2(17 \%)$ & $7(47 \%)$ & - \\
\hline Intermediate & $3(50 \%)$ & $4(33 \%)$ & - & - \\
\hline High & - & $6(50 \%)$ & $8(53 \%)$ & - \\
\hline \multicolumn{5}{|l|}{ Chromosomal anomaly } \\
\hline $\mathrm{t}(4 ; 11)$ & - & $1(8 \%)$ & - & - \\
\hline \multicolumn{5}{|c|}{ Duration of maintenance chemotherapy (years) } \\
\hline Mean \pm SD & - & $1.2 \pm 0.9$ & - & - \\
\hline Minimum & - & 0.08 & - & - \\
\hline Maximum & - & 2.75 & - & - \\
\hline $\begin{array}{l}\text { Prophylactic cranial } \\
\text { irradiation }\end{array}$ & - & $10(83 \%)$ & $8(53 \%)$ & - \\
\hline \multicolumn{5}{|c|}{ Treatment-free period (years) } \\
\hline Mean \pm SD & - & - & $3.5 \pm 3.6$ & - \\
\hline
\end{tabular}

Table 2. Mean and standard deviation values from the natural killer cell cytotoxicity assay at different effector to target cell ratios by group.

\begin{tabular}{|l|c|c|c|c|c|}
\hline $\begin{array}{l}\text { E:T } \\
\text { ratio }\end{array}$ & $\begin{array}{c}\text { Completed } \\
\text { protocol } \mathbf{M} \mathbf{~ n = 6}\end{array}$ & $\begin{array}{c}\text { Maintenance } \\
\text { chemotherapy } \mathbf{n}=\mathbf{1 2}\end{array}$ & $\begin{array}{c}\text { Treatment } \\
\text { discontinued } \mathbf{n}=\mathbf{1 5}\end{array}$ & $\begin{array}{c}\text { Control } \\
\mathbf{n = 1 1}\end{array}$ & $\mathbf{p}$ \\
\hline $1: 1(\%)$ & $20.35 \pm 3.61$ & $48.22 \pm 10.78$ & $24.34 \pm 16.49$ & $20.61 \pm 10.98$ & $\begin{array}{c}\text { Maintenance CT vs. Protocol } \\
\text { M, no treatment, controls: }<0.05 \\
\text { Other comparisons: }>0.05\end{array}$ \\
\hline $10: 1(\%)$ & $37.13 \pm 14.41$ & $63.43 \pm 20.01$ & $51.62 \pm 20.55$ & $40.61 \pm 14.85$ & $>0.05$ \\
\hline $20: 1(\%)$ & $42.04 \pm 15.73$ & $61.54 \pm 18.37$ & $62.67 \pm 25.03$ & $50.57 \pm 15.86$ & $>0.05$ \\
\hline $30: 1(\%)$ & $56.05 \pm 16.12$ & $76.81 \pm 17.54$ & $63.98 \pm 29.38$ & $69.61 \pm 13.33$ & $>0.05$ \\
\hline $50: 1(\%)$ & $69.51 \pm 20.48$ & $81.73 \pm 20.81$ & $71.49 \pm 33.81$ & $77.66 \pm 10.73$ & $>0.05$ \\
\hline $\mathrm{LU}_{50} / 10^{5}$ & $1.38 \pm 0.41$ & $1.77 \pm 0.64$ & $1.64 \pm 0.30$ & $1.55 \pm 0.22$ & $>0.05$ \\
\hline
\end{tabular}

E:T: Effector:Target cell; Maintenance CT: Patients receiving maintenance chemotherapy; Protocol M: Patients who completed protocol M; No treatment: Patients whose treatment was discontinued

The proportion was significantly lower in the maintenance chemotherapy group compared to the control group $(\mathrm{p}<0.05)$, while the difference between the protocol $\mathrm{M}$ and control groups was of borderline significance $(\mathrm{p}=0.06)$.

The mean proportions of $\mathrm{CD}^{+} 6^{+} \mathrm{NKG}_{2} \mathrm{D}^{+}$cells were $9.40 \pm 3.39 \%$ in the protocol M group, $7.23 \pm 2.48 \%$ in the maintenance chemotherapy group, $9.53 \pm 3.83 \%$ in the discontinued treatment group, and $12.94 \pm 6.33 \%$ in the control group. This value was significantly lower in the maintenance chemotherapy group compared to controls $(\mathrm{p}<0.05)$.

Mean proportions of $\mathrm{CD} 95^{+} \mathrm{NKp} 46^{+}$cells were $2.97 \pm 1.41 \%$ in the protocol M group, $2.46 \pm 1.41 \%$ in the maintenance chemotherapy group, $5.34 \pm 4.13 \%$ in the discontinued treatment group, and $6.49 \pm 2.31 \%$ in 
the control group. This value was significantly lower in the protocol M group compared to controls $(\mathrm{p}<0.05)$.

Mean proportions of $\mathrm{CD} 56^{+} \mathrm{CD} 94^{+}$cells were $4.38 \pm 2.49 \%$ in the protocol $\mathrm{M}$ group, $5.47 \pm 2.78 \%$ in the maintenance chemotherapy group, $6.11 \pm 3.18 \%$ in the discontinued chemotherapy group, and $9.59 \pm 5.14 \%$ in the control group. The proportion was significantly lower in patients who had completed protocol M compared to controls $(\mathrm{p}<0.05)$, whereas the difference between those who had finished treatment and the controls was at the boundary of significance $(\mathrm{p}=0.05)$ (Table 3$)$.

\section{Comparison of patients based on prophylactic cranial irradiation \\ $\mathrm{CD} 16^{+} \mathrm{CD} 56^{+}$cell ratio and $\mathrm{NK}$ cytotoxicity at an E:T ratio of 1:1 were compared between patients who did and did not undergo prophylactic cranial irradi- ation. NK cytotoxicity was significantly higher in those who received prophylactic cranial irradiation than in those who did not $(\mathrm{p}<0.05)$ (Table 4). There was no significant difference in the ratio of $\mathrm{CD} 16^{+} \mathrm{CD} 56^{+}$cells ( $\mathrm{NK}$ cell count).}

\section{Comparison of groups based on prophylactic cranial irradiation}

NK cell counts and activity in the maintenance chemotherapy and discontinued treatment groups were compared based on history of prophylactic cranial irradiation. Eighty-three percent of patients in the maintenance chemotherapy group had undergone prophylactic cranial irradiation. There was no significant difference between those who did and did not receive prophylactic cranial irradiation in terms of NK activity expressed in LU. The mean proportion of $\mathrm{CD} 16^{+} / \mathrm{CD} 56^{+}$ cells was $3.80 \pm 2.15 \%$ in patients who had received prophylactic cranial irradiation $5 \pm 1.41 \%$ in those who had not $(p>0.05)$. Fifty-three percent of patients who had finished treatment had received prophylactic cranial irradiation. Cytotoxic activity at a 1:1 E:T ratio was higher among those who had received prophylactic cranial irradiation compared to those who had not, but the difference was not significant. The mean LU value was $1.49 \pm 0.24$ in the prophylactic cranial irradiation group and $1.75 \pm 0.31$ in the group without prophylactic cranial irradiation. In the discontinued treatment group, the mean proportion of $\mathrm{CD} 16^{+} \mathrm{CD} 56^{+}$cells was $5.81 \pm 3.98 \%$ for those who had received prophylactic cranial irradiation and $8.05 \pm 4.01 \%$ for those who had not received prophylactic cranial irradiation, but the difference was not significant (Table 5).

\section{Comparison of patients based on risk group}

Within-group comparisons of NK cell ratio and activity were made based on the patients' risk groups. Fifty percent of patients in the protocol M group were at standard risk and the rest were in the intermediate-risk group. The mean $\mathrm{LU}$ value of the standard-risk group was $1.51 \pm 0.49$ and the mean proportion of $\mathrm{CD} 16^{+} \mathrm{CD} 56^{+}$cells was $4.48 \pm 3.31 \%$. Of the patients receiving maintenance chemotherapy, $16 \%$ were in the standard-risk group, 34\% were in the intermediate-risk group, and $50 \%$ were in the high-risk group. The $\mathrm{CD} 16^{+} \mathrm{CD} 56^{+} \mathrm{NK}$ cell population was larger in the standard-risk group compared to the high-risk group, but the difference was not significant. Forty-seven percent of the patients whose treatment was discontinued were in the standard-risk group and $53 \%$ were in the high-risk group. Mean LU value was $1.75 \pm 0.31$ in the standard-risk group and the mean $\mathrm{CD} 16^{+} \mathrm{CD} 56^{+}$cell ratio was $8.05 \pm 4.01 \%$.

\section{Comparison of patients based on length of treat- ment-free period}

NK cell ratio and activity were compared between patients whose treatment was discontinued $\leq 1$ year earlier and $>1$ year earlier. The mean NK activity at an E:T ratio of $1: 1$ was $22.36 \pm 15.87 \%$ in patients who were treatment-free for $\leq 1$ year and $26.32 \pm 18.35 \%$ for those who were treatment-free for $>1$ year. $\mathrm{CD} 16^{+} \mathrm{CD} 56^{+}$cell ratios in these groups were $5.05 \pm 3.58 \%$ and $8.06 \pm 4.02 \%$, respectively. There was no significant difference between the groups.

\section{Comparison of groups based on immunophe- notypes \\ NK activity and LU at E:T 1:1 and NK ratio were compared within the groups based on immunopheno-}


Table 3. Receptor expression by group.

\begin{tabular}{|c|c|c|c|c|c|}
\hline Receptors (\%) & Protocol M & Maintenance CT & $\begin{array}{c}\text { Treatment } \\
\text { discontinued }\end{array}$ & Controls & $\mathbf{p}$ \\
\hline $\begin{array}{l}\text { CD3 } \\
\text { CD16 } \\
\end{array}$ & $17.00 \pm 2.94$ & $18.78 \pm 6.81$ & $16.78 \pm 4.95$ & $19.57 \pm 5.62$ & $>0.05$ \\
\hline $\begin{array}{l}\text { CD3 } \\
\text { CD56 } \\
\end{array}$ & $7.25 \pm 4.27$ & $10.11 \pm 6.03$ & $11.09 \pm 5.96$ & $14.29 \pm 8.71$ & $>0.05$ \\
\hline $\begin{array}{l}\mathrm{CD}^{+} \\
\mathrm{CD}^{+} 6^{+} \\
\end{array}$ & $12.49 \pm 6.69$ & $11.25 \pm 5.94$ & $9.57 \pm 5.36$ & $7.32 \pm 2.74$ & $>0.05$ \\
\hline $\begin{array}{l}\mathrm{CD}^{+} \\
\mathrm{CD}^{+} 6^{+} \\
\end{array}$ & $3.55 \pm 1.63$ & $5.24 \pm 4.51$ & $3.31 \pm 1.20$ & $2.78 \pm 1.99$ & $>0.05$ \\
\hline $\begin{array}{l}\mathrm{CD}^{+} 6^{+} \\
\mathrm{CD}^{+} 6^{+}\end{array}$ & $4.04 \pm 2.64$ & $4.00 \pm 2.04$ & $6.77 \pm 4.01$ & $9.75 \pm 6.80$ & $\begin{array}{c}>0.05 \\
\text { Protocol M vs. controls: } \mathrm{p}=0.06 \\
\text { Maintenance CT vs. controls: } \\
\mathrm{p}<0.05\end{array}$ \\
\hline $\begin{array}{l}\mathrm{CD}_{16}{ }^{+} \\
\mathrm{NKG}_{2} \mathrm{D}^{+}\end{array}$ & $9.40 \pm 3.39$ & $7.23 \pm 2.48$ & $9.53 \pm 3.83$ & $12.94 \pm 6.33$ & $\begin{array}{c}>0.05 \\
\text { Maintenance CT vs. controls: } \\
\mathrm{p}<0.05\end{array}$ \\
\hline $\begin{array}{l}\mathrm{CD}^{+} \\
\mathrm{NKG}^{+} \mathrm{D}^{+}\end{array}$ & $50.88 \pm 12.08$ & $51.58 \pm 14.70$ & $39.97 \pm 7.87$ & $43.53 \pm 7.66$ & $\begin{array}{c}>0.05 \\
\begin{array}{c}\text { Maintenance CT vs. No treat- } \\
\text { ment: } \mathrm{p}=0.047\end{array}\end{array}$ \\
\hline $\begin{array}{l}\mathrm{CD}^{+} \\
\mathrm{CD}^{+} 6^{+}\end{array}$ & $13.67 \pm 5.67$ & $9.46 \pm 3.45$ & $9.45 \pm 4.23$ & $13.35 \pm 5.18$ & $>0.05$ \\
\hline $\begin{array}{l}\mathrm{CD} 94^{+} \\
\mathrm{NKp}_{4} 6^{+}\end{array}$ & $2.97 \pm 1.41$ & $2.46 \pm 1.41$ & $5.34 \pm 4.13$ & $6.49 \pm 2.31$ & $\begin{array}{c}>0.05 \\
\text { Maintenance CT vs. controls: } \\
\mathrm{p}<0.05\end{array}$ \\
\hline $\begin{array}{l}\mathrm{CD}^{2} 6^{+} \\
\mathrm{CD}^{+} 4^{+}\end{array}$ & $4.38 \pm 2.49$ & $5.47 \pm 2.78$ & $6.11 \pm 3.18$ & $9.59 \pm 5.14$ & $\begin{array}{l}\quad>0.05 \\
\text { Protocol M vs. controls: }<0.05 \\
\text { No treatment vs. controls: } 0.05\end{array}$ \\
\hline
\end{tabular}

CT: Chemotherapy, Protocol M: Completed Protocol M; No treatment: Treatment discontinued

type. There was a significant difference in $\mathrm{CD} 16^{+} \mathrm{CD} 56^{+}$ ratio between the $\mathrm{B}$ and $\mathrm{T}$ cell immunophenotypes in the group whose treatment was discontinued $(\mathrm{p}<0.05)$.

\section{Distribution of cytokine levels by group}

IL-15 and IFN- $\gamma$ levels measured from samples obtained before (unstimulated, serum level) and after (stimulated, with tumour cells) the NK activity assay was evaluated in the different treatment groups. In the samples taken before the assay, the maintenance chemotherapy and discontinued treatment groups had significantly lower IFN- $\gamma$ levels compared to the control group $(\mathrm{p}<0.05)$. Other differences were not significant.

\section{DISCUSSION}

In this study, NK cell activity was evaluated both as a percentage of cytotoxicity and as $\mathrm{LU}_{50} / 10^{5}$ at different E:T ratios in children at various stages of ALL treatment compared to a control group. When evaluated as $\mathrm{LU}_{50} / 10^{5}$, NK cell activity was highest in the patients receiving maintenance chemotherapy, but the difference was not significant. The percentage of NK cell activity at a 1:1 E:T ratio of the group receiving maintenance chemotherapy was higher than in the patients who had completed protocol $\mathrm{M}$, the patients whose treatment was discontinued, and the control group. Sørskaar et al. evaluated NK cell activity in children with ALL and found that NK cell activity in the peripheral blood and bone marrow was significantly lower in these patients at time of diagnosis compared to normal healthy controls, while there was no difference in activity between patients in remission and the control group. However, the small number of patients and the fact that the control group consisted of healthy adults instead of children makes it difficult to interpret the results of their study (20). Another study including a larger patient series showed that NK activity (calculated from a LU/ $10^{7}$ $20 \%$ kill rate) was significantly lower in children with ALL receiving maintenance chemotherapy when 
Table 4. Comparison of all patients based on prophylactic cranial irradiation.

\begin{tabular}{|l|c|c|}
\hline & E:T 1:1 (\%) & CD16 $^{+}$CD56 $^{+}(\%)$ \\
\hline PCI+ & $40.69 \pm 16.23(\mathrm{n}=13)$ & $4.69 \pm 3.17(\mathrm{n}=18)$ \\
\hline PCI- & $22.99 \pm 14.5(\mathrm{n}=13)$ & $5.90 \pm 3.59(\mathrm{n}=14)$ \\
\hline P & $0.007^{\star}$ & $>0.05$ \\
\hline
\end{tabular}

${ }^{\star} \mathrm{p}<0.05$; E:T: Effector:target cell; PCI: Prophylactic cranial irradiation

Table 5. Comparison of groups based on prophylactic cranial irradiation.

\begin{tabular}{|c|c|c|}
\hline & $\begin{array}{c}\text { Maintenance } \\
\text { chemotherapy } n=12 \\
\end{array}$ & $\begin{array}{c}\text { Treatment } \\
\text { discontinued } n=15\end{array}$ \\
\hline \multicolumn{3}{|l|}{ PCI+ } \\
\hline $\mathrm{n}$ & $10(83 \%)$ & $8(53 \%)$ \\
\hline E:T 1:1 & $48.06 \pm 11.51 \%$ & $28.90 \pm 16.62 \%$ \\
\hline $\mathrm{LU}_{50} / 10^{5}$ & $1.77 \pm 0.68$ & $1.49 \pm 0.24$ \\
\hline $\mathrm{CD} 16^{+} / \mathrm{CD} 56^{+}$ & $3.80 \pm 2.15 \%$ & $5.81 \pm 3.98 \%$ \\
\hline \multicolumn{3}{|l|}{ PCI- } \\
\hline $\mathrm{n}$ & $1(8 \%)$ & $7(47 \%)$ \\
\hline E:T 1:1 & $49.54 \%$ & $21.08 \pm 16.86 \%$ \\
\hline $\mathrm{LU}_{50} / 10^{5}$ & 1.81 & $1.75 \pm 0.31$ \\
\hline $\mathrm{CD}_{16}{ }^{+} \mathrm{CD} 56^{+}$ & $5 \pm 1.41 \%$ & $8.05 \pm 4.01 \%$ \\
\hline $\mathrm{p}$ & & $0.05<$ \\
\hline
\end{tabular}

E:T: Effector:target cell; LU: Lytic unit; PCI: Prophylactic cranial irradiation

compared to adult and pediatric controls, while there was no significant difference in LU between patients whose treatment was discontinued and the control group (21). Similarly, a comparison of 22 children with ALL receiving maintenance chemotherapy and healthy controls demonstrated that the ALL patients had relatively lower NK cell activity even if NK cell count was normal, but their NK cell activity also normalised within a few months of treatment cessation (22). Our findings are not consistent with the aforementioned studies. The NK cell population is known to increase both in size and activity over the lifetime of an individual (23). This offers no explanation for the higher NK cell activity we observed in the group of patients receiving maintenance chemotherapy, who did not differ from the other groups in terms of age distribution. In a study on Hodgkin's disease, NK cell activity was found to be increased compared to the control group in patients treated with radiotherapy or radiotherapy + chemotherapy, similar to our study (24). It is known that radiotherapy to the brain induces changes in the immunolog- ic status of the children (25). Eighty-three percent of the children in our maintenance chemotherapy group underwent prophylactic cranial irradiation just before maintenance chemotherapy was initiated. Yamada et al. reported significant increases in NK cell activity immediately after irradiation in children with ALL who underwent 24 Gy of prophylactic cranial irradiation. They also reported that when lymphocytes obtained from healthy persons were subjected to 20 Gy radiation in vitro, NK activity increased by 1.4 times compared to cells that were not irradiated $(\mathrm{p}<0.05)$, but that activity decreased significantly when the exposure was increased to $50 \mathrm{~Gy}$. When the late effects of radiotherapy were evaluated, the mean NK activity of irradiated patients was higher compared to non-irradiated patients and the control group. They investigated whether this was related to a decrease in suppressor $\mathrm{T}$ lymphocytes or a humoral effect, and determined that radiotherapy had a direct stimulatory effect on NK cells (26). Another study also documented increased mean NK cell activity level in healthy subjects after low-dose radiation (27). In our study, most patients (83\%) in the maintenance chemotherapy group had received 12-18 Gy of radiation. In addition, our statistical analysis of the entire patient group indicated that NK cytotoxicity was significantly higher among patients who received prophylactic cranial irradiation compared to those who did not. Studies reporting low NK cell activity may have had different rates of prophylactic cranial irradiation than in our patient group. The increase in NK activity in our maintenance chemotherapy group may be interpreted in this way.

In the present study, when we analysed receptor expression by group in order to evaluate the activity-receptor relationship, the $\mathrm{CD} 16^{+} \mathrm{CD}^{2} 6^{+}$(NK cell) population was significantly reduced in the group that had completed protocol $\mathrm{M}$ and the group receiving maintenance chemotherapy compared to controls. Similar to our study, Mazur et al. compared the $\mathrm{CD} 16^{+} \mathrm{CD} 56^{+}$population in children with ALL immediately after completing protocol II and 1 year later to a control group and found this cell population to be lower in the group receiving intensive chemo- 
therapy compared to the other groups (28). In a prospective study by Eyrich et al., 20 standard and intermediate-risk pediatric patients with ALL who had not received radiotherapy were evaluated in terms of cellular and humoral immunity at various stages of chemotherapy. The authors observed that NK cells were within normal limits at diagnosis, but that their numbers decreased like other lymphocytes with intensive chemotherapy, and that after a short recovery period at the end of induction phase II, they remained below the normal range during reinduction and maintenance chemotherapy. However, they rose again 3-6 months after treatment cessation (29). Cytokines were also investigated in this prospective study. IL-4, IL-7, IL-13, IL-15, IFN- $\gamma$, and TGF $\beta$ levels were evaluated and minor changes were observed in the levels of these cytokines during the course of treatment. In our study, IFN- $\gamma$ and IL-15 levels in various treatment groups were evaluated before and after mononuclear cell stimulation by tumour cells. Levels of IFN- $\gamma$ and IL-15 were significantly lower only in the unstimulated samples from the maintenance chemotherapy and discontinued treatment groups compared to the control group.

The intensity and duration of chemotherapy significantly affect immune functions, and intensity of chemotherapy is determined according to risk group. Ek et al. compared standard-, intermediate-, and high-risk groups in childhood ALL and determined that there were persistent abnormalities in the T, B, and NK cell subpopulations in the high-risk group even 6 months after treatment (30). In our evaluation of patients by risk group, mean LU and NK cell ratios were higher in patients who completed protocol $\mathrm{M}$ in the standard-risk group compared to those in the intermediate-risk group. The rate of CD16/CD56 positivity was higher in the standard-risk group compared to the other risk groups. Among patients whose treatment had been discontinued, the standard-risk group was superior in terms of both NK activity and NK cell count. Similar to the study by Ek et al., NK functions were both qualitatively and quantitatively higher in the standard-risk group (i.e., in patients receiving less intensive chemotherapy), but the differences were not statistically significant.

The group of patients whose treatment had been discontinued was evaluated based on the length of treatment-free period. Cytotoxic activity and LU at $\mathrm{E}: \mathrm{T}$ of $1: 1$ and $\mathrm{CD} 16^{+} \mathrm{CD} 56^{+}$ratio tended to be lower in patients with shorter ( $\leq 1$ year) treatment-free period compared to those with longer periods ( $>1$ year), but the difference was not significant. The $\mathrm{CD} 16^{+} \mathrm{CD} 56^{+}$ratio of the patients whose treatment had been discontinued was lower compared to the control group. In a study by Kovacs et al., one or more cellular immunity parameters were below normal range in $41.9 \%$ of children with leukemia $15 \pm 4.4$ months after chemotherapy cessation. NK activity was decreased in $16.3 \%$ and ADCC was decreased in $18.6 \%$ of children with leukemia (31).

In the present study, we aimed to quantitatively and functionally assess NK cell activity in children with ALL at various stages of chemotherapy and to relate these features with clinical findings. Unlike other studies in the literature, we evaluated both NK activity and NK cell receptors together. We also took into consideration the patients' risk groups and whether the patients underwent cranial irradiation. The limitation of the study is that there were limited number of patients in each group. The small number of patients per group and their nonhomogeneous distribution in our study made statistical evaluation difficult. Changes in NK cell activity and count with age in healthy individuals necessitates the formation of age subgroups in larger case series. In addition, a prospective study of children with acute leukemia in different stages of chemotherapy is needed to evaluate specific changes with different chemotherapeutic agents. Evaluating both humoral and cellular immunity in children with ALL will provide a comprehensive understanding of this system.

Peer Review: Externally peer-reviewed.

Hakem Değerlendirmesi: Dış bağımsız.

Ethics Committee Approval: Ethics committee approval for this study was obtained from the Local Ethics Committee of Istanbul University, Istanbul Faculty of Medicine (Ethic Number: 2006/519). 
Etik Komite Onayı: Bu çalışma için etik komite onayı İstanbul Üniversitesi, İstanbul Tıp Fakültesi Yerel Etik Kurulu'ndan alınmıştır (Dosya No: 2006/519).

Informed Consent: Written consent was obtained from the participants.

Bilgilendirilmiş Onam: Katılımcılardan bilgilendirilmiş onam alınmıştır.

Author Contributions: Conception/Design of Study- T.A.U., Z.K., S.E.K.; Data Acquisition- T.A.U., B.Ç., S.K., N.A., B.A., G.D.; Data Analysis/Interpretation- T.A.U., B.Ç., S.K., N.A., B.A., G.D.; Drafting Manuscript- T.A.U., Z.K., S.E.K.; Critical Revision of Manuscript- Z.K., S.E.K.; Final Approval and Accountability- T.A.U., Z.K., S.E.K., B.Ç., S.K., B.A., N.A., G.D.

Yazar Katkıları: Çalışma Konsepti/TasarımT.A.U., Z.K., S.E.K.; Veri Toplama- T.A.U., B.Ç., S.K., N.A., B.A., G.D.; Veri Analizi/Yorumlama- T.A.U., B.Ç., S.K., N.A., B.A., G.D.; Yazı Taslağı- T.A.U., Z.K., S.E.K.; İçeriğin Eleştirel İncelemesi- Z.K., S.E.K.; Son Onay ve Sorumluluk- T.A.U., Z.K., S.E.K., B.Ç., S.K., B.A., N.A., G.D.

Conflict of Interest: Authors declared no conflict of interest.

Çıkar Çatışması: Yazarlar çıkar çatışması beyan etmemişlerdir.

Financial Disclosure: This work was supported by the grant of Scientific Research Projects Coordination Unit of Istanbul University, Istanbul Faculty of Medicine (Project No: T-889/02062006).

Finansal Destek: Bu çalışma İstanbul Üniversitesi Bilimsel Araştırma Projeleri Koordinasyon Birimi hibesi ile desteklenmiştir (Proje Numarası: T-889/02062006).

\section{REFERENCES}

1. Miller JS. The biology of natural killer cells in cancer, infection, and pregnancy. Exp Hematol 2001;29(10):1157-68.

2. Ishigami $S$, Natsugoe $S$, Tokuda $K$, Nakajo $\mathrm{A}$, Che $\mathrm{X}$, Iwashige $\mathrm{H}$, et al. Prognostic value of intratumoral natural killer cells in gastric carcinoma. Cancer 2000;88(3):577-83.

3. Standish LJ, Torkelson C, Hamill FA, Yim D, HillForce A, Fitzpatrick A, et al. Immune defects in breast cancer patients after radiotherapy. J Soc Integr Oncol 2008;6(3):110-21.

4. Pierson BA, Miller JS. CD56+bright and CD56+dim natural killer cells in patients with chronic myelogenous leukemia progressively decrease in number, respond less to stimuli that recruit clonogenic natural killer cells, and exhibit decreased proliferation on a per cell basis. Blood 1996;88(6):2279-87.

5. Zuelzer WW, Inoue S, Thompson RI, Ottenbreit MJ. Long-term cytogenetic studies in acute leukemia of children; the nature of relapse. Am J Hematol 1976;1(2):143-90.

6. Yabuhara A, Kawai H. A recycling defect as a characteristic of natural killer cells in childhood acute lymphoblastic leukemia. Pediatr Res 1990;28(6):572-78.

7. Van Tilburg CM, van der Velden VHJ, Sanders EAM, Wolfs TFW, Gaiser JF, de Haas V, et al. Reduced versus intensive chemotherapy for childhood acute lymphoblastic leukemia: Impact on lymphocyte compartment composition. Leuk Res 2011;35(4):484-91.

8. Perkins JL, Harris A, Pozos TC. Immune Dysfunction After Completion of Childhood Leukemia Therapy. J Pediatr Hematol Oncol 2017;39(1):1-5.

9. Wakiguchi H, Kubota H, Hisakawa H, Fujieda M, Kurashige T. Defective natural killer cell activity and deficient production of interferon- $\gamma$ in children with acute lymphoblastic leukemia. Pediatr Int 1994;36(4):361-5.

10. Burchenal JH, Murphy ML. Long-term survivors in acute leukemia. Cancer Res 1965;25(9):1491-4.

11. Möricke A, Zimmermann M, Reiter A, Henze G, Schrauder A, Gadner H, et al. Long-term results of five consecutive trials in childhood acute lymphoblastic leukemia performed by the ALLBFM study group from 1981 to 2000. Leukemia 2010;24(2):265-84.

12. Aksu Uzunhan T, Karakas Z, Erdem Kuruca S, 
Cetin B, Karadenizli S, Akdeniz N, et al. The Impact of Chemotherapy on Natural Killer Cells in Children with Acute Lymphoblastic Leukemia. J Child 2011;11(4):160-9.

13. Flohr T, Schrauder A, Cazzaniga G, PanzerGrümayer R, van der Velden V, Fischer S, et al. Minimal residual disease-directed risk stratification using real-time quantitative PCR analysis of immunoglobulin and T-cell receptor gene rearrangements in the international multicenter trial AIEOP-BFM ALL 2000 for childhood acute lymphoblastic leukemia. Leukemia 2008;22(4):771-82.

14. Lange BJ, Bostrom BC, Cherlow JM, Sensel MG, La MKL, Rackoff W, et al. Double-delayed intensification improves event-free survival for children with intermediate-risk acute lymphoblastic leukemia: a report from the Children's Cancer Group. Blood 2002;99(3):825-33.

15. Schlager SI, Adams AC. Use of Dyes and Radioisotopic Markers in Cytotoxicity Tests. Methods Enzymol 1983;93:233-45.

16. Atasever B, Ertan NZ, Erdem-Kuruca S, Karakas $Z$. In vitro effects of vitamin $C$ and selenium on NK activity of patients with $\beta$-thalassemia major. Pediatr Hematol Oncol 2006;23(3):187-97.

17. Mosmann T. Rapid colorimetric assay for cellular growth and survival: Application to proliferation and cytotoxicity assays. J Immunol Methods 1983;65(1-2):55-63.

18. Jonges LE, Albertsson P, van Vlierberghe RL, Ensink NG, Johansson BR, van de Velde CJ, et al. The phenotypic heterogeneity of human natural killer cells: presence of at least 48 different subsets in the peripheral blood. Scand J Immunol 2001;53(2):103-10.

19. Cook EB, Stahl JL, Lowe L, Chen R, Morgan E, Wilson J, et al. Simultaneous measurement of six cytokines in a single sample of human tears using microparticle-based flow cytometry: Allergics vs. non-allergics. J Immunol Methods 2001;254(1-2):109-18.

20. Sørskaar D, Lie SO, Førre O. Natural killer cell activity of peripheral blood and bone marrow mononuclear cells from patients with childhood acute lymphoblastic leukemia. Acta Paediatr Scand 1985;74(3):433-7.

21. Jermy A, Lilleyman JS, Jennings R, Rees RC. Spontaneous natural killer cell activity in childhood acute lymphoblastic leukaemia. Eur J Cancer Clin Oncol 1987;23(9):1365-70.

22. Aricò M, Lanfranchi A, Molinari E, Maccario R, Nespoli L, Burgio GR. Cell-mediated cytotoxicity in children during and after therapy for acute lymphoblastic leukemia. Pediatr Hematol Oncol 1988;5(4):279-86.

23. Abo T, Cooper MD, Balch CM. Postnatal expansion of the natural killer and keller cell population in humans identified by the monoclonal HNK-1 antibody. J Exp Med 1982;155(1):321-6.

24. Pinel MI, Esteves EB, Rumjanek VM. Natural killer cell activity in Hodgkin's disease patients undergoing radiation therapy or chemotherapy and radiation therapy. Clin Lab Haematol 1998;20(5):303-6.

25. Kebudi R, Ayan I, Darendeliler E, Agaoglu L, Ekmekçioglu S, Yagci T, et al. Immunologic status in children with brain tumors and the effect of therapy. J Neurooncol 1995;24(3):219-27.

26. Yamada S, Kawai H, Miyagawa Y, Komiyama A. Effect of Radiotherapy on Natural Killer Activity in Childhood Acute Lymphoblastic Leukemia and Lymphoma. Leuk Lymphoma 1991;4(5-6):343-9.

27.Zarcone D, Tilden AB, Lane VG, Grossi CE. Radiation sensitivity of resting and activated nonspecific cytotoxic cells of T lineage and NK lineage. Blood 1989;73(6):1615-21.

28. Mazur B, Olejnik I, Wylezol I, Sonta-Jakimczyk D, Szczepanski T, Karpe J. Assessment of chosen parameters of the immune system in children with acute lymphoblastic leukemia. Pediatr Hematol Oncol 2003;20(4):303-8.

29. Eyrich M, Wiegering V, Lim A, Schrauder A, Winkler B, Schlegel PG. Immune function in children under chemotherapy for standard risk acute lymphoblastic leukaemia - a prospective study of 20 paediatric patients. Br J Haematol 2009;147(3):360-70.

30. Ek T, Mellander L, Andersson B, Abrahamsson 
J. Immune reconstitution after childhood acute lymphoblastic leukemia is most severely affected in the high risk group. Pediatr Blood Cancer 2005;44(5):461-8.
31. Kovacs GT, Barany O, Schlick B, Csoka M, Gado J, Ponyi A, et al. Late immune recovery in children treated for malignant diseases. Pathol Oncol Res 2008;14(4):391-7. 